\title{
Distress: To Treat or Not to Treat?
}

\author{
Andrew A. Nierenberg, MD
}

In one of our research group meetings, we took an informal poll to find out who would prescribe a benzodiazepine to someone who was acutely grieving, felt anxious, was experiencing some insomnia, and wanted relief from distress. The younger among us mostly would prescribe while those of us who are grizzled would mostly refrain from doing so. Coincidentally, within the next week, one of my patients called requesting exactly that. One of her parents had died and she was anticipating becoming overwhelmed. She was afraid that she would "Iose control" at the funeral. To prevent this from happening, she asked if there was anything I could give her. While expressing my sympathy for her loss, I told her that I did not have anything that would relieve her distress; the loss of a loved one is a painful part of the human condition for which no pill seemed appropriate. The research group discussion and the patient both bring up important questions about the nature of distress, psychiatry, neuropsychiatry, and psychopharmacology.

For clinicians, alleviating patients' suffering, decreasing pain and distress, and improving functioning are obvious laudable goals for psychiatry and neuropsychiatry. But these goals present concrete philosophical challenges for thoughtful clinicians. Patients present with a complaint that prompts them to seek help. Clinicians diagnose the problem and prescribe treatment. If the treatment works, patients' distress is decreased and the treatment is declared successful; the goals of treatment are reached. In many cases, this model works. A patient with an episode of major depression remits with an antidepressant and appropriate psychotherapy. Another patient with schizophrenia is freed of hallucinations and delusions, and is able to function. Yet another patient with seizures and post-ictal confusion is stabilized and can lead a normal life. But what about someone, like the patient described earlier, who is grieving the loss of a loved one and feeling almost intolerable anguish and painful yearning, and requests medication to lessen their distress? What about someone who is struggling with loneliness and intimacy issues, and feels anxious about developing relationships? What about someone who stays in a dysfunctional marriage and feels constantly dysphoric and empty? What about someone who learns that they have multiple sclerosis and mourns the loss of their future? In these instances, it is not so clear that clinicians can easily treat their patients' distress.

Distress is defined as hurt, suffering, pain, anguish, torment (condensed in the marvelous Yiddish word tsoris-meaning troubles and suffering from those troubles). ${ }^{1}$ The spectrum of distress reflects the human condition. Causes of distress include loss of important people

Dr. Nierenberg is professor of psychiatry at Harvard Medical School, co-director of the Bipolar Clinic and Research Program, and associate director of the Depression Clinical and Research Program at Massachusetts General Hospital (MGH) in Boston.

Faculty Disclosures: Dr. Nierenberg consulted to or served on the advisory boards of Abbott, Appliance Computing, Inc., Brain Cells, Inc., Bristol-Myers Squibb, Eli Lilly, EpiQ, Forest, GlaxoSmithKline, Janssen, Jazz, Merck, Novartis, Pam Labs, Pfizer, PGx Health, Pharmaceutica, Schering-Plough, Sepracor, Shire, Somerset, Takeda, and Targacept; he has received research support from Cederroth, Cyberonics, Forest, Medtronics, NARSAD, NIMH, Ortho-McNeil-Janssen, Pam Labs, Pfizer, Shire, and the Stanley Foundation through the Broad Institute; he has received past support from Bristol-Myers Squibb, Cederroth, Eli Lilly, Forest, GlaxoSmithKline, Janssen, Pfizer, Lictwer Pharma, and Wyeth; he has received honoraria from the MGH Psychiatry Academy (MGHPA activities are supported through Independent Medical Education grants from Astra Zeneca, Eli Lilly, and Janssen; he earns fees for editorial functions for CNS Spectrums through MBL Communications, Inc., and Psychiatric Annals through Slack, Inc.; he receives honoraria as a CME Executive Director for the Journal of Clinical Psychiarty through Physiciáns Postgraduate Press; he has been on the speaker's bureaus of Bristol-Myers Squibb, Cyberonics, Eli Lilly, Forest, GlaxoSmithKline, and Wyeth; he has received royalties from Cambridge University Press and Belvoir Publishing; he owns stock options in Appliance Computing, Inc.; and owns the copyrights to the Clinical Positive Affect Scale and the MGH Structured Clinical Interview for the Montgomery Asberg Depression Scale, exclusively licensed to the MGH Clinical Trials Network and Institute. 
(through disruptions of relationships, death, moving), important roles (spouse, parent, child, employee, employer, friend), status, money, freedom, dignity, autonomy, independence, time, a vision of the future, hope, bodily integrity, and overall ability to function, to name a few. Hallmarks of borderline personality disorder include distress intolerance ${ }^{2}$ and greater reactivity and intensity of negative affect ${ }^{3}$ coupled with dysfunctional coping strategies. Diagnostic and Statistical Manual of Mental Disorders, Fourth Edition Axis I psychiatric disorders can interfere with distress tolerance and the emerging neuroscience of stress has illuminated psychopathological mechanisms and suppression of neurogenesis. ${ }^{4}$

Perhaps one of the preventive neuropsychiatric mechanisms of action of focused cognitive behavioral therapy to prevent depressive relapse is that it decreases the experience of distress in response to stressful situations. ${ }^{5}$ Similarly, Dialectical Behavioral Therapy is designed to help patients regulate their emotional responses to stress and learn how to become more resilient and less distressed when experiencing strong emotions. ${ }^{6}$ Mindfulness based cognitive therapy helps patients put their distress in context and provides them with mediation tools to self-soothe. ${ }^{7}$ Dignity Therapy is designed to help terminally ill patients deal with existential issues and come to terms with their death with less distress. ${ }^{8}$

Since distress comes in so many forms, what are the best treatments? For most DSM-IV Axis I disorders, treating the underlying disorder will alleviate distress. For many psychosocial issues, appropriate psychotherapy may help. But what about those frequent situations that are more difficult to categorize? Anticipatory anxiety associated with grief; distress about loss of function after a cerebrovascular infarct; distress upon learning of a diagnosis of multiple sclerosis; and so on. What is the best course of action to help those patients who lack resilience? ${ }^{9}$ How can we help our patients achieve psychological well-being ${ }^{10}$ and increase their resilience? And when is distress an appropriate response that should not be treated?

As psychiatry moves (rightly so) toward systematic assessment, " evidence-based and measurement-based psychiatric care, ${ }^{12}$ clinicians expert in psychopharmacology are at risk of losing the art of listening, of constructing a narrative to understand the sources of distress, and of knowing when patients should experience their distress without pharmacologic treatment. To be overly symptom based and to seek pharmacologic responses to distress in every instance may cause more harm than good. Compassion (contained in the Yiddish word rachamonas) and understanding, and sometimes just listening and being there, may allow those who are suffering from distress to pass through their most difficult challenges. With regard to grief in particular, the best advice I have heard to give comfort to bereaved patients is that no one gets over it; instead, they are transformed by it. Thus, will prescribing a benzodiazepine to those who are distressed in grief interfere with that transformation? If insomnia after grief persists, when would it be appropriate to prescribe? What is the most therapeutic response to a patient who learns of a serious neuropsychiatric diag nosis? Perhaps the best way to approach these difficult issues is with humility, caring, curiosity, clinical judgment, peer supervision, and a touch of wisdom. CNS

\section{REFERENCES}

1. Distress - definition of distress by the Free Online Dictionary. Thesaurus and Encyclopedia Available at: http://www.thefreedictionary.com/distress. Accessed June 1, 2009.

2. Gratz KL, Rosenthal MZ, Tull MT, Lejuez CW. Gunderson JG. An experimental investigation of emotion dysregulation in borderline personality disorder. $J$ Abnorm Psychol. 2006:115:850-855.

3 Selby EA, Anestis MD, Bender TW, Joiner TE Jr. An exploration of the emotional cas cade model in borderline personality disorder. J Abnorm Psychol. 2009;118:375-387.

4. Zhao C, Deng W, Gage FH. Mechanisms and Functional Implications of Adult Neurogenesis. Cell. 2008;132:645-660

5. Butler AC, Chapman JE, Forman EM, Beck AT. The empirical status of cognitive-behavjoral therapy: A review of meta-analyses. Clin Psychol Rev. 2006;26:17-31.

6. Linehan MM, Schmidt H. The Dialectics of Effective Treatment of Borderline Personality Disorder. In: O'Donohue W, Krasner L, eds. Theories of behavior therapy: Exploring behavior change. Washington DC: American Psychological Association; 1995:553-584.

7. Lau MA, Segal ZV. Mindfulness-based cognitive therapy as a relapse prevention approach to depression. In: Witkiewitz K, Marlatt GA, eds. Therapist's guide to evidencebased relapse prevention. San Diego, CA: Elsevier Academic Press; 2007:73-90.

8. Chochinov HM, Hack T, Hassard T, Kristjanson LJ, McClement S, Harlos M. Dignity Therapy: A Novel Psychotherapeutic Intervention for Patients Near the End of Life. $J$ Clin Oncol. 2005;23:5520-5525.

9. Feder A, Nestler EJ, Charney DS. Psychobiology and molecular genetics of resilience. Nat Rev Neurosci. 2009;10:446-457.

10. Ryff CD, Singer B. Psychological well-being: meaning, measurement, and implications for psychotherapy research. Psychother Psychosom. 1996;65:14-23.

11. Rush AJ, First MB, Blacker DA. Handbook of Psychiatric Measures. 2nd ed. Washington DC: American Psychiatric Publishing; 2008.

12. Nierenberg AA, Ostacher MJ, Borreili DJ, et al. The integration of measurement and management for the treatment of bipolar disorder: A STEP-BD model of collaborative care in psychiatry. J Clin Psychiatry. 2006;67:3-7 